\title{
AKURASI
}

p-ISSN : 2720-9067

e-ISSN : 2685-1059

Program Studi Magister Akuntansi

Fakultas Ekonomi dan Bisnis

Universitas Mataram

\section{WHAT FACTORS AFFECT STUDENTS' WHISTLEBLOWING INTENTIONS?}

Refita Yayang Nur'aini ${ }^{1}$, Sri Pujiningsih'

Program Studi Akuntansi, Fakultas Ekonomi, Universitas Negeri Malang ${ }^{12}$

${ }^{12}$ Corresponding author: sri.pujiningsih.fe@,um.ac.id

\section{INFORMASI ARTIKEL}

Article history:

Dikirim tanggal: 30/07/2021

Revisi pertama tanggal: 20/10/2021

Diterima tanggal: 27/10/2021

Tersedia online tanggal 27/12/2021

\section{ABSTRAK}

Perilaku berani mengungkap sebuah kecurangan atau pelanggaran oleh mahasiswa akuntansi, yang nanti berkarir sebagai akuntan dan profesi lainnya adalah sangat penting. Penelitian ini menguji variabel yang memengaruhi intensi whistleblowing dalam perspektif teori perilaku terencana (TPB). Pendekatan survei dilakukan dengan sampel mahasiswa akuntansi sebanyak 154. Uji regresi digunakan untuk menguji pengaruh variabel sikap, norma subjektif dan kontrol perilaku terhadap intensi whistleblowing mahasiswa akuntansi. Hasil penelitian menyimpulkan ketiga variabel tersebut memengaruhi secara positif signifikan terhadap intensi whistle blowing, dengan variabel sikap memiliki pengaruh yang paling besar yaitu sebesar 37\% dibandingkan dua variabel lainnya. Pembentukan karakter sikap mahasiswa akuntansi penting dalam proses pembelajaran akuntansi untuk mendukung perilaku whistleblowing. Dosen akuntansi sebagai bagian dari indikator norma subjektif mahasiswa berperan penting dalam pembentukan karakter tersebut. Hasil penelitian ini berkontribusi bagi pemegang kebijakan untuk membangun whistleblowing system di perguruan tinggi.

Kata Kunci: akuntansi, mahasiswa, pelaporan pelanggaran, teori perilaku terencana

\begin{abstract}
Accounting students' courageous behavior in exposing fraud or violation is critical for their future careers as accountants and other professions. This research examines the variables that influence whistleblowing intentions through the Theory of Planned Behavior (TPB) lens. A survey approach was used to gather data from 154 accounting students. The effect of attitude variables, subjective norms, and behavioral control on accounting students' whistleblowing intentions was examined using a regression test. The regression analysis indicated that all three variables influenced whistleblowing intentions positively. Among the three variables, attitude towards behavior has the biggest impact on whistleblowing intentions, at 37\%. Building accounting students' attitude character is important to encourage whistleblowing action. As for indicators of student subjective norms, accounting lecturers play a critical role in developing these characters. The findings of this study assist policymakers in developing a university-based whistleblowing system.
\end{abstract}

Keywords: accounting, college students, theory of plan behavior, whistleblowing 


\section{Introduction}

Whistleblowing is the act of a person reporting or providing information to authorities about suspected criminal conduct or fraud. In the context of accounting, whistleblowing refers to the accountant's role in exposing the existence of a fraud involving their profession (Handika \& Sudaryanti, 2017). As a result, accountants and potential accountants must possess the desire, mindset, and awareness to act as whistleblowers. Accountants' role as whistleblowers in exposing fraud is critical (Abdullah \& Hasma, 2017) because whistleblowing is regarded as an efficient method of detecting fraud (Handika \& Sudaryanti, 2017). As many accountants were involved in fraud scandals (Elias, 2008), it takes courage for accountants to uncover fraud (Putra \& Maharani, 2018).

Numerous factors influence individuals' willingness to act as whistleblowers (Scheetz \& Wilson, 2019). For instance, individual intentions will affect whistleblowing activities (Winardi, 2013). The study employed Ajzen's (1991) Theory of Planned Action (TPB). According to Ajzen (1991), three elements influence behavioral intentions: behavioral control, subjective norms, and attitudes. Examples of whistleblowing behavior were carried out by Sherron Watkins in the Enron case, Cynthia Cooper in the WorldCom case, and Joe Speaker in the Rite Aid case (Dyck et al., 2010).

According to Pujiningsih \& Sulastri (2012), educator accountants support and value reporting on corporate social initiatives. Additionally, this study makes use of TPB. Educator accountants should also be involved in ethics education, particularly concerning whistleblowing. For this reason, the practice of disclosing fraud is critical for accounting students and prospective accountants (Elias, 2008). They should also be taught not to engage in deceptive behavior while on campus. The study's findings shed light on various types of fraud committed by students, including plagiarism, fraudulent attendance, exam cheating, and data manipulation (Putra \& Maharani, 2018). Meanwhile, only a few universities continue to build a whistleblowing system (WBS) to acclimate students to whistleblowing (Pertiwi, 2019). Indeed, the whistleblowing system has been found to minimize or eliminate fraud (Indra, 2018).

Several universities, including Brawijaya University, Bina Nusantara University, Gajah Mada University, and Indonesia, have adopted a whistleblower system (Pertiwi, 2019). Additional efforts are required to urge universities to adopt WBS. Additionally, the WBS's effectiveness requires the dedication of all members of the organization (Winardi, 2013). Tumuramye et al. (2018) suggest that whistleblowing-supporting institutions, such as the Whistleblower Protection Act, be reviewed and improved to enable whistleblower intents and behavior to be carried out. Since 2008, Indonesia has had a WBS-style guide known as the Reporting and Violation System Guidelines (Sistem Pelaporan dan Pelanggaran-SPP) published by the National Committee on Governance Policy.

Individuals may face ethical issues while disclosing fraud if the WBS is enforced (Hidayati \& Pustikaningsih, 2016). However, if the individual possesses self-control and believes his behavior would be tolerated, he will reveal fraud (Sulistomo \& Prastiwi, 2012). Several prior studies on the disclosure of fraud using TPB were conducted with mixed findings. Attitudes positively affect whistleblowing intentions (Putra \& Maharani, 2018; Alleyne et al., 2013; Trongmateerut \& Sweeney, 2013; Park \& Blenkinsopp, 2009). 
However, other studies show that attitudes did not affect whistleblowing intents (Algadri et al., 2019; Rustiarini \& Sunarsih, 2017; Suryono \& Chariri, 2016; Handika \& Sudaryanti, 2017).

Lasmini \& Ramantha (2019), Indra (2018), Parianti et al. (2016), Trongmateerut $\&$ Sweeney (2013), Carpenter \& Reimers (2005) have researched the positive effect of subjective norms on whistleblowing intentions. The findings of these studies contradict those of Rustiarini \& Sunarsih (2017), who found that subjective norms affect whistleblowing intentions. Meanwhile, Algadri et al. (2019), Tarjo et al. (2019), Putra \& Maharani (2018) demonstrated that behavioral control has a negative effect on whistleblower intentions. The findings of this study contradict previous research such as Park \& Blenkinsopp (2009), Yoga et al. (2017), Damayanthi et al. (2017), and Latan et al. (2018), which all concluded that behavioral control has a positive effect on whistleblowing intentions.

Respondents in several earlier research included police officers, civil officials, and students. The novelty of this study is the research subject, namely accounting students at different universities who have not applied the whistleblowing system. Variations in the organizational environment may produce different findings. Additionally, this research was motivated by inconsistent research findings with student responses. Based on the critical function of the whistleblower and the relevance of accounting students daring to expose fraud (Abdullah \& Hasma, 2017; Handika \& Sudaryanti, 2017; Putra \& Maharani, 2018), this research aims to explain the factors that influence students' whistleblowing intention whether attitudes, subjective norms, or behavioral control affect their intentions. This research is expected to contribute to TPB, especially in research related to accounting ethics. In addition, this research is expected to contribute to organizational policy development in support of its whistleblowing system deployment.

\section{Theoretical Framework and Hypothesis Development}

This research uses the Theory of Planned Behavior (TPB) to explain the direction of the relationship and the magnitude of the influence of attitude variables, subjective norms, and behavioral control on students' intentions to whistleblowing. TPB aims to identify a person's intentions or motivations for certain behaviors. The intention is a desire to behave, while the behavior is a real action someone has done. While the intention is a desire to behave, behavior is actual behavior performed by someone (Jogiyanto, 2007). The assumption is that intention serves as a filter for motivational elements that can impact behavior. Indication of intention is the degree to which an individual is willing to try or the extent to which an individual intends to exert effort in performing an activity (Ajzen, 1991). According to TPB, the intention is determined by perceived behavioral control, subjective norms, and attitude toward the behavior (Abdullah \& Hasma, 2017). According to Jogiyanto (2007:65), three beliefs determine human behavior: behavioral beliefs, normative beliefs, and control beliefs. Behavioral beliefs will shape or establish attitudes toward certain behaviors, favoring or disfavoring them.

Meanwhile, normative beliefs provide subjective norms, while control beliefs generate behavioral control (Jogiyanto, 2007:66). The more a person's intention to behave in a particular way, the greater the likelihood that person will take that behavior (Siallagan 
et al., 2017). Within the framework of this study's theme, it is suspected that the greater the intention or desire to undertake whistleblowing, the greater the likelihood that the student will do so. Figure 1 depicts the link between the variables in the TPB.

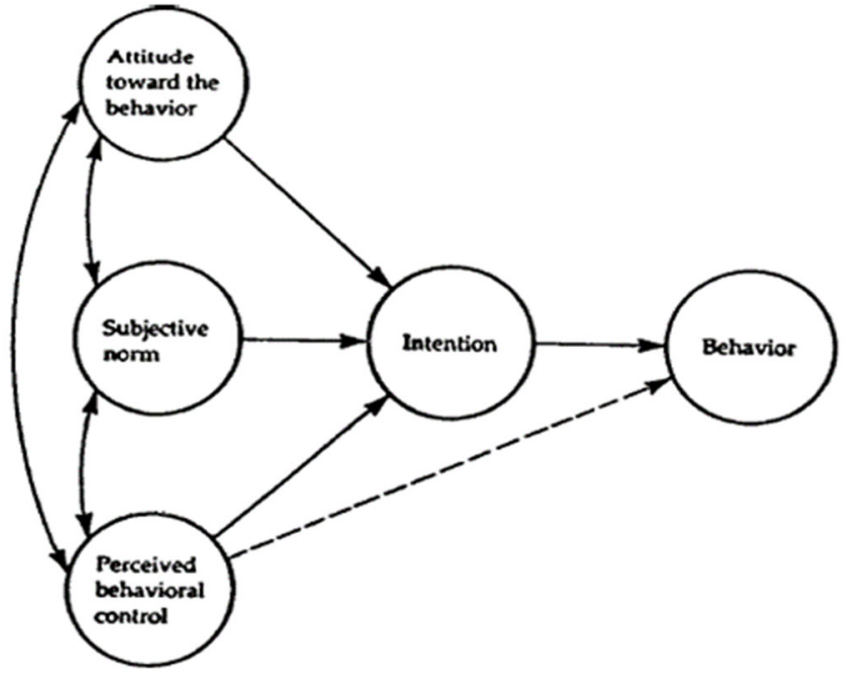

Figure 1. Theory of Planned Behavior

Attitude is a person's evaluation of the advantage of engaging in a particular behavior (Ajzen, 1991). Attitude is a good or bad assessment of an action based on the individual's judgment and belief about the behavior's consequences and the appraisal of those outcomes (Tarjo et al., 2019). According to research conducted by Trongmateerut \& Sweeney (2013), the whistleblowing intention was associated with the cultural contexts of Thailand and the United States. The findings of this study indicate that attitudes do affect whistleblower intentions. This finding is interesting because it indicates that attitudes affect behavioral intentions regardless of the cultural setting. This means that respondents believe whistleblowing benefits and have a favorable attitude toward it. The theoretical implication of this research is to bolster the application of TPB, namely that the more favorable one's attitude about whistleblowing, the greater one's intention to be a whistleblower. Other studies proved that attitude influences whistleblow intentions (Park \& Blenkinsopp, 2009; Zakaria et al., 2016) with police respondents in South Korea and Malaysia. In comparison, Sulistomo \& Prastiwi (2012), Putra \& Maharani (2018), and Indra (2018) used student respondents. Therefore, based on the TPB and the findings of prior research, this study hypothesizes the following:

$\mathrm{H}_{1}$ : Attitude has a positive effect on student whistleblowing intentions

Subjective norm is the impact of others on a person's decision to perform or refrain from performing specific acts (Jogiyanto, 2007:42). According to Ajzen (2005), subjective norms are the factors that influence a person's decision to take or refrain from taking specific behavior in response to societal pressure. According to empirical studies, subjective norms have a positive and significant effect on whistleblowing intentions (Handika \& Sudaryanti, 2017; Lasmini \& Ramantha, 2019; Parianti et al., 2016; Park \& Blenkinsopp, 2009; Zakaria et al., 2016). This could mean that the respondent's intention 
for whistleblowing is influenced by social pressure and the influence of others. In other words, the high whistleblowing intention of respondents is affected by high social pressure and the impact of others. The higher the student's subjective norms, the higher the intention to engage in whistleblowing activity. The following hypothesis is based on the TPB and past studies:

$\mathrm{H}_{2}$ : Subjective norms has a positive effect on student whistleblowing intentions

Ajzen (1991) stated that behavior control is a person's perception of the ease or difficulty of performing certain acts. Another school of thought suggests that behavioral control is a person's view of their actions (Sulistomo \& Prastiwi, 2012). Perceived behavioral control is more about an individual's belief in his power to act and the things he considers while deciding on an action (Rustiarini \& Sunarsih, 2017). Behavioral control has a significant positive effect on a person's whistleblowing intention. Several research results that support this have been carried out by several researchers (Handika \& Sudaryanti, 2017; Parianti et al., 2016; Park \& Blenkinsopp, 2009; Rustiarini \& Sunarsih, 2017; Siallagan et al., 2017; Winardi, 2013). This suggests that respondents' ease and confidence in their abilities to whistleblower will boost their intention to do so. The more straightforward it is for students to engage in whistleblowing, the greater their intention to do so, and the more confident students are that they are capable of doing so, the greater their intention to do so (Handika \& Sudaryanti, 2017; Parianti et al., 2016). This research hypothesizes the following based on the TPB framework and past research studies:

$\mathrm{H}_{3}$ : Behavioral control has a positive effect on student whistleblowing intentions

\section{Research Methods}

The purpose of this study is to explain the effect of attitude toward behavior, subjective norms, and perceived behavioral control on accounting students' whistleblowing intentions. The target population for this study is the 250 accounting students at the Universitas Negeri Malang (UM) class of 2016. The sampling technique uses proportional random sampling, calculated by the Slovin formula. The sample size is 154 students.

A survey on perceived attitudes, behavior control, subjective norms, and whistleblowing intentions uses a questionnaire with a Likert Scale measurement (Suliyanto, 2018:134). The Likert scale has four response levels, namely 4 for a strong agreement, 3 for agreement, 2 for disagreement, and 1 for strong disagreement. The researchers consider only four alternatives, with justifications, to avoid bias. In terms of variable measurement, the researchers followed the research of Rustiarini \& Sunarsih (2017). Table 1 summarizes the measurement and indicator variables.

The questionnaire was pilot tested on 30 students before its distribution for data collection to determine its reliability and validity. The Cronbach Alpha value for the four variables, namely whistleblower intention, attitudes, subjective norms, and behavioral control, was greater than 0.70 , indicating that the questionnaire was reliable. Meanwhile, the questionnaire's validity value is greater than 0.279 for all four variables, indicating validity. 
Table 1. Variable Measurement

\begin{tabular}{llll}
\hline No & \multicolumn{1}{c}{ Variable } & & \multicolumn{1}{c}{ Indicators } \\
\hline $\mathbf{1} \quad$ Whistleblowing & 1. & desire to do whistleblowing \\
& intention & 2. & willingness to try whistleblowing \\
& 3. & plan to do whistleblowing \\
& & & \\
& 1. & whistleblowing as good action \\
& 2. & whistleblowing is perceived as useful \\
& 3. & whistleblowing is perceived as the preferred action \\
& 4. & whistleblowing is perceived as important \\
& Subjective norms & 1. & the opinion of important people to do whistleblowing \\
& 2. & the importance of other people's opinions to do whistleblowing \\
& 3. & the personal expectation that many people do whistleblowing \\
& 4. & the influence of people who are valued and respected to do \\
& & whistleblowing \\
& Behavioral control & 1. & confidence in being able to do whistleblowing \\
& 2. & have the capacity to do whistleblowing \\
& 3. & wish to do whistleblowing \\
& 4. & whistleblowing with self-control \\
\hline
\end{tabular}

Multiple linear regression is the data analysis technique used. Before conducting the regression test, the researcher performed a series of classical assumption tests, including a normality test, a heteroscedasticity test, and a multicollinearity test. These three classical assumptions have been satisfied. The following formula expresses the equation for the multiple linear regression function:

$$
\mathrm{Y}=\mathrm{a}+\mathrm{b} 1 \mathrm{X} 1+\mathrm{b} 2 \mathrm{X} 2+\mathrm{b} 3 \mathrm{X} 3+e
$$

Where:

$$
\begin{aligned}
& \mathrm{Y}=\text { whistleblowing intention } \\
& \mathrm{b}=\text { regression coefficient } \\
& \mathrm{a}=\text { constant } \\
& \mathrm{e}=\text { error } \\
& \mathrm{X} 1=\text { attitude } \\
& \mathrm{X} 2=\text { subjective norm } \\
& \mathrm{X} 3=\text { behavior control } \\
& e \quad=\text { error term }
\end{aligned}
$$

\section{Results and Discussion}

Before evaluating the regression model, a correlation analysis was performed to determine the direction between the dependent variable, whistleblowing intention, and the three independent variables: attitudes, subjective norms, and behavioral control. The correlation coefficients between variables are shown in Table 2. Pearson Correlation coefficients of $0.667,0.497$, and 0.537 , respectively, indicate that the variables attitude, subjective norms, and behavioral control are all positively connected with whistleblowing intents at a 0.000 level of significance. 
Table 2. Correlation

\begin{tabular}{lcc}
\hline & Pearson Correlation & Significance \\
\hline Attitudes & 0,667 & 0,000 \\
Subjective norms & 0,497 & 0,000 \\
Behavioral control & 0,573 & 0,000 \\
\hline
\end{tabular}

After establishing the association with a correlation test, a regression test was used to ascertain the degree and direction of the relationship between the dependent and independent variables. The regression test's results are summarized in Table 3.

Table 3. Regression Results Summary

\begin{tabular}{|c|c|c|c|c|c|c|}
\hline \multirow[b]{2}{*}{ Model } & & \multicolumn{2}{|c|}{$\begin{array}{c}\text { Unstandardized } \\
\text { Coefficients }\end{array}$} & \multirow{2}{*}{$\begin{array}{c}\begin{array}{c}\text { Standardized } \\
\text { Coefficients }\end{array} \\
\text { Beta } \\
\end{array}$} & \multirow[b]{2}{*}{$\mathbf{T}$} & \multirow[b]{2}{*}{ Sig. } \\
\hline & & B & Std. Error & & & \\
\hline (Constant) & & 1,262 & 0,702 & & 1,799 & 0,074 \\
\hline Attitudes & & 0,387 & 0,051 & 0,497 & 7,589 & $0,000 *$ \\
\hline Subjective norms & & 0,137 & 0,044 & 0,209 & 3,117 & $0,002 *$ \\
\hline Behavioral control & & 0,149 & 0,060 & 0,177 & 2,474 & $0,014^{*}$ \\
\hline$F$ test & $=56,495$ & & & & & \\
\hline Sig. F test & $=0,000$ & & & & & \\
\hline R Squared & $=0,530$ & & & & & \\
\hline Adjusted R Squared & $=0,521$ & & & & & \\
\hline
\end{tabular}

Additionally, the $\mathrm{F}$ value was calculated to evaluate the regression model. The $\mathrm{F}$ test significance value is less than 0.05 . This indicates that the variables attitude, subjective norms, and behavioral control simultaneously have a strong beneficial effect on the variable accounting students' whistleblowing intentions. Table 3 shows the $\mathrm{R}$ squared value of 0.53 . This can be interpreted that the factors that affect the whistleblowing intention of accounting students are influenced by $53 \%$ of the attitude variables, subjective norms, and behavioral control. In contrast, the remaining $47 \%$ are influenced by other factors or variables.

The individual parameter significance test results show that the attitude variable has a positive significant coefficient at $\mathrm{p}<0.05$. This finding indicates that the attitude variable positively affects accounting students' whistleblowing intention. As a result, the null hypothesis is rejected, and the alternative hypothesis is accepted. Subjective norms also have a significant value and a positive coefficient $(\mathrm{p}<0.05)$. This suggests that subjective norms positively affect accounting students' whistleblowing intentions. This signifies that the null hypothesis is rejected, and the alternative hypothesis, $\mathrm{H}_{2}$, is accepted. The behavioral control variable is significant at $\mathrm{p}<0.05$ and has a positive coefficient. Hence, $\mathrm{H}_{3}$ is accepted.

The influence of attitude on whistleblowing intentions has a positive and significant effect, as shown in Table 3. According to Table 3, the attitude variable has a $38.7 \%$ effect on the whistleblowing intention of accounting students. According to descriptive statistical data, most respondents answered the statement "whistleblowing or reporting fraud that I did was a good action and should have been done" compared to other statements. This 
indicates that students believe whistleblowing is a "beneficial action," which ultimately influences their decision to do so. Jogiyanto (2007) refers to the behavioral beliefs that motivate whistleblowers. When accounting students behave in this manner, they can find whistleblowing once they become accountants (Handika \& Sudaryanti, 2017; Putra \& Maharani, 2018).

Meanwhile, in accordance with Carpenter \& Reimers (2005), students feel that whistleblowing will result in good consequences. According to the descriptive statistics for the variable of whistleblowing intention, the majority of respondents selected the statement, "I plan to report fraud (whistleblowing) when I become aware of fraud." These findings can also explain why, when most students believe that whistleblowing is good behavior that must be practiced, the intention to engage in whistleblowing is high, as evidenced by "planning" the behavior. As explained in the TPB's definition of intention, one of the indicators of intention is planning (Ajzen, 1991).

This study successfully demonstrated H1's acceptance of a positive attitude toward behavior on whistleblowing intentions. Park \& Blenkinsopp (2009), Winardi (2013), Zakaria et al (2016), Sulistomo \& Prastiwi (2012), Putra \& Maharani (2018), dan Indra (2018) all support this conclusion. Compared to the other two independent variables, the magnitude of this variable relationship is $38.7 \%$. This means that behavior attitudes most influence the whistleblowing intention variable. However, this finding is different from Suryono \& Chariri's (2016), that attitudes have no significant effect on the intentions of civil servants to become whistleblowers. This is due to the possibility that civil servants will not dare to bear the risks and consequences of whistleblowing. Also, Handika \& Sudaryanti (2017) explained that attitude had no significant effect on accounting students' whistleblowing intention. Again, this could be due to apprehension about the risks and consequences of their actions. The findings of these two studies can be used to demonstrate the existence of an ethical dilemma (Hidayati \& Pustikaningsih, 2016).

Table 3 shows a significant positive effect of subjective norms on whistleblowing intentions. The subjective norm variable can explain $13.7 \%$ of the factors influencing accounting students' whistleblowing intentions. Based on descriptive statistics, most respondents chose the first indicator, namely the opinion of important people who engage in whistleblowing. This can be interpreted as the influence of people regarded as necessary by respondents when they dare to report fraud being the dominant subjective norm in accounting students. Accounting students are motivated to report fraud by people important to them, such as family, lecturers, and friends. As a result, they must encourage and lead by example regarding whistleblowing. Furthermore, Universitas Negeri Malang, like other universities, must establish a whistleblowing system (Pertiwi, 2019), as well as the commitment of the entire academic community to do so (Winardi, 2013). Students will not face ethical dilemmas when reporting or disclosing fraud if this is done (Hidayati \& Pustikaningsih, 2016).

Subjective norms will be created due to normative beliefs (Jogiyanto, 2007). The greater the influence of important people on accounting students, the greater their intention to "plan" to do whistleblowing. Park \& Blenkinsopp (2009), Winardi (2013), Zakaria et al (2016), Sulistomo \& Prastiwi (2012), Parianti et al (2016), Lasmini \& Ramantha (2019) all support this conclusion. Compared to the other two variables, the magnitude of the 
influence of the normative trust variable on the intention to report fraud is $13.7 \%$. Based on these findings, lecturers and parents must encourage students to disclose fraud. Subjective norms significantly affect students' intentions, indicating that social pressure from important people such as friends, lecturers, and parents influences their intentions. Accountant educators as lecturers can play an important role in shaping the character of whistleblowing attitudes (Pujiningsih \& Sulastri, 2012). This finding differs from Rustiarini \& Sunarsih (2017), who explains that subjective norms do not affect government auditors' whistleblowing intentions. This could be due to the existence of a code of ethics requiring auditors, including government auditors, to conduct audits independently. Meanwhile, the findings of this study with student respondents are generally normative (Pujiningsih \& Sulastri, 2012).

The influence of behavioral control on whistleblowing intentions has a significant effect, as shown in Table 3. The whistleblowing intention of accounting students can be explained by $14.9 \%$ of the behavioral control variables. According to descriptive statistics, the majority of respondents selected the statement, "if I truly want to disclose fraud (whistleblowing), I will do so." This choice relates to the third indicator of behavioral control variables (see Table 1). Thus, self-control is demonstrated by a strong desire to become a whistleblower. This is the primary reason students "plan" to report fraud. This explains the assumption that behavioral control results from control beliefs (Jogiyanto, 2007:66).

The findings of this study corroborate those of Park \& Blenkinsopp (2009), Winardi (2013), Rustiarini \& Sunarsih (2017), Sulistomo \& Prastiwi (2012), Parianti et al. (2016), Handika \& Sudaryanti (2017). Park \& Blenkinsopp (2009) researched a sample of South Korean police officers. Winardi (2013) conducted a study on a random sample of civil servant personnel. Rustiarini \& Sunarsih (2017) indicated that behavioral control variables exerted a substantial influence due to the ease with which civil servants perform whistle blows. However, in comparison to the student sample, their behavioral control variable is more focused on self-control than convenience (Handika \& Sudaryanti, 2017; Parianti et al., 2016; Sulistomo \& Prastiwi, 2012). This is most likely owing to the fact that WBS does not have a presence on their campus. This is consistent with the study's context, in which students rely more on self-control because UM does not yet have WBS. This research finding contradicts Putra \& Maharani (2018), who found that behavioral control has little effect on accounting students' whistleblowing intentions. Students are fearful of reprisal by the reported individual (Putra \& Maharani, 2018). Meanwhile, Algadri et al. (2019) concluded the same conclusion in their research with a sample of auditors, that behavioral control did not affect the auditor's intention to do whistleblowing.

\section{Conclusions, Implications, and Limitations}

The results of this study confirm several research findings. First, students' whistleblowing intentions are positively influenced by their attitude. Other research findings found that subjective norms and behavioral control positively affect students' whistleblowing intentions. As a theoretical implication, this study confirmed the applicability of the Theory of Planned Behavior (TPB), particularly in the context of whistleblowing behavior. The practical impact of this research is that it will benefit the 
university's policies concerning academic ethics and integrity. The most crucial factor in accounting students' whistleblowing is the attitude variable, which can be used as input for curriculum development and learning. The lowest influence is from the subjective norms variable. Hence, parents, lecturers, and university support are required to develop a whistleblowing system. In particular, accounting academia can help shape characters who support the attitude variable.

Further research can use prosocial behavior theory to analyze the factors that influence whistleblowing more broadly divided into two major groups, namely antecedent contextual factors and individual antecedent factors. Other variables that affect student whistleblowing intentions account for $47 \%$ of the total. Online questionnaire surveys are also used in the research. It is recommended that future research use questionnaires with direct assistance and other data collection methods such as interview methods or case studies.

\section{References}

Abdullah, M. W., \& Hasma, H. (2017). Determinan Intensi Auditor Melakukan Tindakan Whistleblowing Dengan Perlindungan Hukum Sebagai Variabel Moderasi (Studi pada Inspektorat Provinsi Sulawesi Selatan). EKUITAS (Jurnal Ekonomi Dan Keuangan), 1(3), 385. https://doi.org/10.24034/j25485024.y2017.v1.i3.2096

Ajzen, I. (1991). The Theory of Planned Behavior. Organizational Behavior and Human Decision Processes, 50(2), 179-211. https://doi.org/10.1016/0749-5978(91)90020-T

Ajzen, I. (2005). Attitudes, Personality and Behaviour 2nd-edition. In International Journal of Strategic Innovative Marketing (Vol. 3, p. 117).

Algadri, H. A., Afifudin, \& Junaidi. (2019). Pengaruh Sikap Perilaku, Norma Subjektif, Perepsi Pengendalian Perilaku pada Intention Whistleblowing (Studi pada Kantor Akuntan Publik di Kota Malang). Jurnal Ekonomi Dan Bisnis Universitas Islam Malang, 08(02), 122-135.

Alleyne, P., Hudaib, M., \& Pike, R. (2013). Towards a conceptual model of whistleblowing intentions among external auditors. British Accounting Review, 45(1), 10-23. https://doi.org/10.1016/j.bar.2012.12.003

Carpenter, T. D., \& Reimers, J. L. (2005). Unethical and fraudulent financial reporting: Applying the theory of planned behavior. Journal of Business Ethics, 60(2), 115-129. https://doi.org/10.1007/s10551-004-7370-9

Damayanthi, K. S. R. D., Edy Sujana, S. E., Herawati, N. T., \& AK, S. E. (2017). Pengaruh Norma Subyektif, Sikap Pada Perilaku, Persepsi Kontrol Perilaku Terhadap Niat Melakukan Pengungkapan Kecurangan (Whistleblowing)(Studi Empiris Pada Mahasiswa Akuntansi Program S1 Dan Program D3 Universitas Pendidikan Ganesha). JIMAT (Jurnal Ilmiah Mahasiswa Akuntansi) Undiksha, 8(2).

Dyck, A., Morse, A., \& Zingales, L. (2010). Who blows the whistle on corporate fraud? Journal of Finance, 65(6), 2213-2253. https://doi.org/10.1111/j.15406261.2010.01614.x

Elias, R. (2008). Auditing students' professional commitment and anticipatory socialization and their relationship to whistleblowing. Managerial Auditing Journal, 
23(3), 283-294. https://doi.org/10.1108/02686900810857721

Handika, M. F. D., \& Sudaryanti, D. (2017). Analisis Faktor-Faktor yang Mempengaruhi Niat Mahasiswa Melakukan Tindakan Whistle-Blowing (Studi Pada Mahasiswa Akuntansi STIE Akuntansi Asia Malang). Jurnal Ilmiah Bisnis Dan Ekonomi STIE $A S I A, 11(1), 56-63$.

Hidayati, T. H., \& Pustikaningsih, A. (2016). Pengaruh Komitmen Profesi Dan Self Efficacy Terhadap Niat Untuk Melakukan Whistle Blowing. Nominal, Barometer Riset Akuntansi Dan Manajemen, 5(1). https://doi.org/10.21831/nominal.v5i1.11479

Indra, S. (2018). Analisis Persepsi Mahasiswa Terhadap Niat Melakukan Whistleblowing. Jurnal Penelitan Ekonomi Dan Bisnis, 3(1), 1-11. https://doi.org/10.33633/jpeb.v3i1.2284

Jogiyanto, H. M. (2007). Sistem Informasi Keperilakuan. Andi Offset.

Lasmini, N. N., \& Ramantha, I. W. (2019). Persepsi Mahasiswa Akuntansi Pada Perilaku Whistleblowing. Jurnal Ekonomi Dan Bisnis Universitas Udayana, 10, 1209-1236.

Latan, H., Ringle, C. M., \& Jabbour, C. J. C. (2018). Whistleblowing intentions among public accountants in Indonesia: Testing for the moderation effects. Journal of Business Ethics, 152(2), 573-588. https://doi.org/10.1007/s10551-016-3318-0

Parianti, N. P. I., Suartana, I. W., \& Badera, I. D. N. (2016). Faktor-Faktor Yang Memengaruhi Niat Dan Perilaku Whistleblowing Mahasiswa Akuntansi. Urnal Ekonomi Dan Bisnis Universitas Udayana, 5(12), 4209-4236.

Park, H., \& Blenkinsopp, J. (2009). Whistleblowing as planned behavior - A survey of South Korean police officers. Journal of Business Ethics, 85(4), 545-556. https://doi.org/10.1007/s10551-008-9788-y

Pertiwi, A. P. W. (2019). Pengaruh Komitmen Organisasi Dan Personal Cost Terhadap Niat Aparatur Sipil Negara (ASN) Untuk Melakukan Whistleblowing Dengan Reward Sebagai Variabel Pemoderasi. Sanata Dharma Yogyakarta.

Pujiningsih, S., \& Sulastri. (2012). Sikap Akuntan Pendidik Terhadap Pengungkapan Aktivitas Sosial Perusahaan. Jurnal Akuntansi Aktual, 1(3).

Putra, A. F., \& Maharani, Y. (2018). Niat Melakukan Whistleblowing: Persepsi Mahasiswa Diploma III Ekonomi. Jurnal Akuntansi Indonesia, 7(2), 1-11.

Rustiarini, N. W., \& Sunarsih, N. M. (2017). Factors Influencing the Whistleblowing Behaviour: A Perspective from the Theory of Planned Behaviour. Asian Journal of Business and Accounting, 10(2), 187-214.

Scheetz, A. M., \& Wilson, A. B. (2019). Are not-for-profit employees more willing (or likely) to be whistleblowers? Journal of Public Budgeting, Accounting, and Financial Management, 31(1), 2-25. https://doi.org/10.1108/JPBAFM-06-2018-0054

Siallagan, H., Rohman, A., Januarti, I., \& Din, M. (2017). The effect of professional commitment, attitude, subjective norms, and perceived behavior control on whistleblowing intention. International Journal of Civil Engineering and Technology, 8(8), $508-519$.

Sulistomo, A., \& Prastiwi, A. (2012). Persepsi mahasiswa akuntansi terhadap pengungkapan kecurangan. Universitas Diponegoro, 1-28. 
Suliyanto. (2018). Metode Penelitian Bisnis untuk Skripsi, Tesis, \& Disertasi. Andi Offset.

Suryono, E., \& Chariri, A. (2016). Sikap, Norma Subjektif, Dan Intensi Pegawai Negeri Sipil Untuk Mengadukan Pelanggaran (Whistleblowing). Jurnal Akuntansi Dan Keuangan Indonesia, 13(1), 102-116.

Tarjo, T., Suwito, A., Aprillia, I. D., \& Ramadan, G. R. (2019). Theory of planned behavior and whistleblowing intention. Jurnal Keuangan Dan Perbankan, 23(1), 4357. https://doi.org/10.26905/jkdp.v23i1.2714

Trongmateerut, P., \& Sweeney, J. T. (2013). The Influence of Subjective Norms on Whistle-Blowing: A Cross-Cultural Investigation. Journal of Business Ethics, 112(3), 437-451. https://doi.org/10.1007/s10551-012-1270-1

Tumuramye, B., Ntayi, J. M., \& Muhwezi, M. (2018). Whistleblowing intentions and behavior in Ugandan public procurement. Journal of Public Procurement, 18(2), 111130. https://doi.org/10.1108/JOPP-06-2018-008

Winardi, R. D. (2013). The Influence of Individual and Situational Factors on Lower-Level Civil Servants' Whistle-Blowing Intention in Indonesia. Jurnal Ekonomi \& Bisnis Indonesia (Fakultas Ekonomi Dan Bisnis Universitas Gadjah Mada), 28(3), 361-376. https://doi.org/10.22146/jieb.6216

Yoga, M. R. D., Sujana, E., \& Prayudi, M. A. (2017). Pengaruh Penalaran Moral, Sikap, Norma Subjektif, dan Kontrol Perilaku Terhadap Niat Melakukan Whistleblowing Pada Kecurangan Akademik. E-Journal S1 Ak Universitas Pendidikan Ganesha, 8(2).

Zakaria, M., Abd Razak, S. N. A., \& Yusoff, M. S. A. (2016). The Theory of Planned Behaviour as a Framework for Whistleblowing Intentions. Review of European Studies, 8(3), 221-236. https://doi.org/10.5539/res.v8n3p221 